\title{
Композиційність у сучасній образотворчості: поліфонія чи какофонія?
}

\author{
HATA^IЯ HIKO^АЙЧУK
}

\begin{abstract}
Анотація. Стаття розглядає проблеми композиційності, гармонійності твору у сучасному мистецтві, доводячи, що органічна єАність твору можлива Аише за умови дотримання композиційних законів. Важливого значення автор надає аналізові «візуального Аіалогу» мистецького твору і глядача, роблячи акцент на тому, що завАяки такому піАходу відкривається можливість проникнути у зміст твору, віАчути образ загалом. На переконання автора, композиційне сприйняття скугує необхідним інструментом, щоб вміти бачити і відчувати художній твір. У сучасному мистецтві відбуваються процеси «розгармонізації» твору, і автор статті доводить, що за таких умов мистецтво виступає у ролі своєрідного «комунікативного поля», Ае відбувається Аіалог різних компонентів, що формують загальну культуру. Композиція виступає зв'язуючим компонентом, даючи можливість панорамного погляду на світ. Мистецький твір є своєрідним виразником естетики, інтелігентності, інтелектуального рівня митця, мірилом його моральних якостей. «Провокативність» сучасного мистецтва теж межить у контексті цього Аискурсу; відображаючи авторські рефлексії на виклики і подразники, вона, тим не менше, має свої власні «межі дозволеного». На конкретних приклаАах автор статті доводить, що опанування законів композиційного мислення спричиняє наявність цих меж, зАатність розрізняти статику і динаміку сюжету. Проводячи паралелі у сприйнятті композиції і декомпозиції художником і мистецтвознавцем, автор показує спільне і відмінне у підходах до аналізу одного й того ж твору. Процес композиційного мислення скцадається з чуттєвої та раціональної сторін, що виступають у тісній взаємодії. Працюючи над художнім образом, митець продумує художню дію, у той час як критик рухається зворотнім шляхом. Композиційне мислення породжує Аумки, конструктивно-пластичне вираження поставленого завдання. Аля його вирішення художник зАійснює пошукову роботу, відтворює асоціативне моделювання, трансформуючи простір картини, римуючи угрупування форм. Критик, намагаючись осягнути сенси, закмадені у творі, теж користується композиційним мисленням. Тільки процес розкрутки його творчої думки зворотний. ВіА того, наскільки досконало одні й інші володіють навичками композиційного мислення і сприйняття - залежить результат успішності їх фахової Аіяльності.

За таких умов відкривається сучасна поліфонічність звучання, за інших звук набуває какофонічних характеристик. Що з цього обирати - вирішати митцю.

Ключові слова: образотворче мистецтво, композиція, сучасне мистецтво.
\end{abstract}

Постановка проблеми. Вивчення історичного та сучасного досвіду мистецького навчання композиції Аало змогу виявити позитивні тенденції у здобуванні високого рівня образотворчої грамоти у межах акаАемічної освітньої системи XIX століття, методичні ресурси творчого розвитку особистості у фаховій пеАагогіці початку XX століття, значний потен- ціал освіти сьогодення у соціальному становменні фахівця, зростанні рівня його художньої культури, вихованні самостійності та зАатності Ао творчих звершень, які грунтуються на синтезі наукових і мистецьких аспектів. У естетичному розв'язанні скмадних соціально-просторових завАань сьогодення вагоме значення намежить овоцодінню світовою культурною спаА- 
щиною, вихованню вмінь творчо синтезувати іiі зАобутки із сучасними художніми тенденціями. Це піАсилює актуальність нової якості образотворчої підготовки, застосування широкого спектру методик Аля Ауховного, творчого зростання та самореалізації.

Анаміз останніх АосліАжень і публікацій. Розроблення концепції ролі композиційної Аіяльності у образотворчій піАготовці як нової інтегрованої цілісності з урахуванням її соціальних, освітніх та галузевих перспектив, потребувало вивчення широкого кола проблем. Провідними буки загальнофілософські позиції науки (Арістотель, Г. Гегель, Б. КєАров та ін.), методологія системно-структурного аналізу (І. Бмауберг, А. Гвішіані, В. Гиг, Аж. КАир, Г. ЩеАровицький) та синергетики (С. КурАюмов, I. Пригожин, I. Стенгерс, Г. Хакен), філософія культури (М. Бахтін, В. Біблер, П. Гуревич, М. Каган, Й. Кант, А. Аіхачов, І. Огієнко, М. Хайдеггер та ін.) та освіти (В. Андрущенко, О. Базацук, І. Зязюн, В. Кремень, В. Аутай та ін.), що визначимо наукові підходи у АосліАженні проблеми. Виокремлення науково-психологічного напрямку Аало піАстави визначити структуру особистості фахівця, інтелектуацьні та емоційні якості суб'єктів навчання (Б. Ананьєв, І. Бех, В. Аружинін, Н. Кічук, Б. Коссов, К. Платонов, Г. Селевко, В. Сластьонін, Г. ОАпорт, В. Семиченко, М. Холодна, В. Шадріков та ін.); теоретичні основи розвитку творчого потенціацу індивіда (А. Богоявленська, О. Аеонтьєв, О. Аук, В. Моляко, В. Рибалка, В. Роменець, В. Сєриков, С. Сисоєва та ін.), зокрема у художній сфері (Р. Арнхейм, $\Lambda$. Виготський, В. Зінченко, Є. Крупнік, В. Кузін, А. Аевчук, Б. Мейлах, С. Раппопорт, Н. Рождественська, П. Якобсон та ін.) відповідно до завдань формування особливостей композиційного мислення.

Формукювання мети статті (постановка завАання). Мета статті полягає у науковому обгрунтуванні, розробленні та експериментальній перевірці структури композиційного мислення у системі загальної образотворчої
піАготовки. ВіАповіАно Ао мети було поставмено такі завдання: вивчити та проаналізувати стан розроблення досліджуваної проблеми в науковій $і$ ітературі та світовій мистецькій педагогічній практиці, а також на досвіді роботи з учнями Київської Аитячої школи мистецтв Аослідити генезу та сучасний стан композиціних Аисциплін у системі образотворчої піАготовки; розробити концепцію нових піАходів Ао формування композиційного мислення в системі загальної образотворчої підготовки; теоретично обгрунтувати та розробити модель застосування авторських методик композиційного мислення в системі образотворчої піАготовки; визначити структуру, критерії, показники та рівні сформованості композиційного мислення в сфері образотворчої готовності; зАійснити експериментацьну перевірку авторської модеми композиційного мислення, Аослідити їі ефективність; розробити рекомендації, навчально-методичні матеріали Аля забезпечення формування композиційного мислення в системі загальної образотворчої підготовки.

ВикмаА основного матеріалу АосліАження 3 повним обгрунтуванням отриманих наукових резумьтатів. ПровіАною іАеєю впроваАження засаА композиційного мислення в систему загацьної образотворчої піАготовки $є$ поАоження про синергетичний розвиток системи образотворчої Аіяльності з урахуванням зовнішнього контексту й внутрішніх факторів, що Аає змогу узагальнити сукупність необхіАних знань, умінь і практичних навичок композиційного мислення Аля фахівців у мистецькій сфері, світогляАних і громадянських позицій, моральноетичних цінностей, забезпечує вільне творче зростання особистості в осмисленні та особистісній інтерпретації досвіду художньої культури згіАно із соціальними вимогами та потребами.

Метою та закономірним результатом впровадження нових засаА і піАходів Ао композиційного мислення у системі образотворчої піАго- 
товки $€$ інтегральне особистісне новоутворення, що містить високу мотивацію, усвідомкення цінностей професії, інтегровану цілісність культурологічних, художніх і проектних знань, умінь та навичок, індивіАуацьний творчий АосвіА розв'язання фахових образотворчих завАань, професійно вагомі особистісні якості, зАобуті у результаті рефлексивного опанування надбань художньої культури, що Аає змогу самореалізуватися у соціацьному просторі.

ВіАповіАно Ао теоретичних основ формування композиційного мислення в системі мистецької освіти зумовцено синтезом загального, особливого та індивідуацьного пізнання: поперше, в її трактуванні як феномена культури у станов енні світогАяАу та художньої культури особистості, зАатності Ао цілісного хуАожнього сприйняття в єАності емоційних та раціональних процесів; по-Аруге, у фаховій спрямованості навчання як інструменту неперервного професійного зростання, становленні композиційної образотворчої грамотності як переАумови їхньої повноцінної участі в універсацьному процесі художнього формотворення; потретє, у розвитку образотворчої креативності, пошуку індивіАуальної художньої манери розв'язання професійних завдань.

ТраАиційним шляхом в композиційній освіті кількох століть було набуття професійної майстерності, що коригувалося за художніми якостями. Вивчення генези образотворчої піАготовки у контексті сучасності Аало підстави Аля виокремлення незаперечних освітніх зАобутків: персоніфікований характер навчання у співтворчості майстра та учня, синкретичність творчої Аіяльності; наукові принципи засвоєння кмасичних традицій мистецтва, компмексне опанування теоретичних і практичних Аисциплін, Аосягнення високого рівня графічної майстерності в академічній художній освіті; АосвіА виховання творчих рис засобами мистецтва у різноманітних методичних піАходах та експериментах, акцентоване пізнання граматики формотворення в евристичному, пошу- ковому навчанні мистецтва у модерністський період; чітка організаційна структура та стаАійність сучасної мистецької освіти, яка має значний потенціал у розв'язанні соціальних, естетичних завдань.

Сукупність історичних Ааних та результати аналізу чинної освітньої практики спонукають зробити висновок про те, що сучасний стан компонента формування композиційного мислення в системі образотворчої піАготовки потребує оновлення наукових підходів, технологій та методик мистецького навчання Аля комплексного забезпечення творчого розвитку майбутніх фахівців.

Компхексний проблемно-цільовий, нормативно-порівняльний, історикологічний аналіз значного обсягу Ажерец Аав піАставу виявити стан розроблення проблеми у світовій та вітчизняній науці та практиці, що піАтверАимо особливу актуальність розбудови системи образотворчої піАготовки як піАсистеми неперервної мистецької освіти, котрий зможе реалізуватися у різних виАах художньо-професійної Аіяльності, буде зАатним творчо розв'язувати соціокультурні та естетичні завдання у сучасному суспільстві. У процесі аналізу теорії та практики образотворчої підготовки у історичній ретроспективі виявцено, що її незаперечним надбанням $є$ зАавна випробуваний синтез творчої Аіяльності, художнього навчання та реальної практики, співтворчість майстра та учня, науковість та грунтовність опанування кмасичних традицій мистецтва в єАності теорії та практики, АосвіА евристичного пізнання основ художнього формотворення. У цілому сформована сучасна мистецька піАготовка має чітку стадійність, розвинений методичний комплекс, що визначає їі значний потенціал у розв'язанні соціальних, естетичних завАань. Проте вона характеризується збереженням вузькофахового прагматичного піАходу, низьким ступенем використання розвивацьного впливу мистецтва, неАоречним пануванням тенденцій академічного традиціоналізму 
в методиках виклаАання композиційних Аисцип ін, що зумов ює потребу істотного оновмення наукових підходів і запровадження інновацій у практику образотворчого навчання. Фундаментування концепції образотворчої піАготовки у рамках гуманістичної та кумьтуромогічної параАигми з позицій інтеграції системно-синергетичного, особистісного, компетентнісного наукових підходів спрямовує пеАагогічний процес на особистість, забезпечує розвиток Ауховно-творчого потенціалу, інтемектуамьну та морамьну свободу, виховання ціннісного ставлення Ао професії та кумьтури АюАства, стійке прагнення до саморозвитку й самовАосконацення у мистецькому пізнанні. Ефективність розгортання процесу образотворчої піАготовки забезпечується низкою концептуамьних іАей, зокрема: віАповіАності змісту мистецького навчання вимогам професійної практики; цікеспрямованого виховання креативності засобами мистецтва, творчому засвоєнні й трансформації здобутків науки та практики; гнучкій організації навчально-виховного процесу на основі інтеграції змісту мистецьких і суміжних Аисципмін.

Композиційна образотворча піАготовка становить собою скмадну поміфункціонацьну системно-синергетичну цікісність, що характеризується Аинамічним синтезом культурологічного, художньо-професійного та креативно-особистісного аспектів, зАійснюється через суб'єктсуб'єктні Аіалогічні віАносини, забезпечує високоякісну професійно спрямовану мистецьку освіту віАповіАно Ао соціальних вимог і потреб архітектурної галузі. В умовах сучасних змін, які відбуваються у націонацьній освіті, система образотворчої піАготовки розвивається у Аіамектичному поєАнанні глобацьних інтеграційних процесів й мокамьного інтенсивного розвитку регіонів, що відображається у посименні їх автономії, збереженні кращих традицій, запроваАженні новацій та Аинамічному модемюванні змісту навчання, піАвищенні якісних результатів підготовки фахівців.
Модель образотворчої підготовки у могічній взаємозумовценості цікьового, змістового, процесуацьного, оцінювацьно-резумьтативного блоків як піАсистем їі розвитку та функціонування сприяє розв'язанню виявлених суперечностей сучасної мистецької освіти. Цільовий блок зумов ює мету та завдання образотворчої піАготовки як становцення професійної хуАожньої кумьтури, отримання комплексу мистецьких знань і вмінь, розширення АосвіАу самостійної художньої творчості, виховання креативно-особистісних якостей. Змістовий бцок передбачає організацію взаємодії художніх композиційних Аисциплін, інтегративне опанування яких забезпечує набування необхідних знань, умінь та ціннісних орієнтацій. Процесуамьний блок визначений освітніми функціями образотворчої піАготовки та зумовмює вибір новітніх технологій, комплексу пеАагогічних методів, форм та засобів зАійснення фахово спрямованого образотворчого навчання. Оцінювамьнорезультативний блок відображає процес і peзукьтати моніторингу навчацьних досягнень студентів та сформованість їх образотворчої готовності до професійної Аіяльності.

Аієва реалізація модемі образотворчої піАготовки забезпечується інноваційними засаАами мистецького навчання, запроваАженням різних ступенів поліпредметної інтеграції, синтезом змісту образотворчих та проектних Аисципмін, систематизацією та універсахізацією мистецьких знань і вмінь, засвоєнням та структуруванням світового художньокумьтурного АосвіАу за загацьними композиційними категоріями та поняттями, виокремленням наскрізних тематичних оАиниць змісту Аисципмін. Виявцено, що інтегрування методів станов ення професійної художньої кумьтури, формування образотворчої грамотності та креативності, віАповіАних їм варіантних організаційних форм та видів навчацьних занять, педагогічний моніторинг спімьних результатів наукової та суспімьної Аіямьності, теоретичних і практичних художніх навчальних Аосягнень, комплексний 
аналіз та наскрізне коригування процесу підготовки, взаємопроникнення художніх і проектних завдань уможиивлює перехіА віА репроАуктивної Ао синтезуючої навчацьно-творчої Аіяльності, опанування специфіки творчості в синтезі образних і Аогічних аспектів художнього пізнання, становцення апарату професійного спілкування та індивідуальної художньої манери майбутнього фахівця.

Обгрунтування структурних компонентів образотворчої готовності Ао професійної Аіяльності Аало піАстави Аля виокремлення критеріїв та показників її сформованості. Аоведено, що мотиваційно-ціннісний критерій відображає стійкість професійних мотивів, адекватних цілям і функціям образотворчої Аіяльності фахівця, усвіАомлення естетики та значення в світовому культурному прогресі, інтеграційно-гностичний - узагацьнює особистісний АосвіА спілкування з мистецтвом у вимірах образотворчої грамотності у єАності теоретичних та практичних знань, умінь і навичок, творчоАіяльнісний - Аає змогу простежити характер виявів образотворчої креативності на шияху накопичення індивіАуального АосвіАу продуктивної діяльності.

Конкретні показники щодо кожного з них відображують інтегруючі універсальні виміри: знання, розуміння, операції, анаціз, синтез. Виокремлення чотирьох рівнів сформованості образотворчої готовності Ао професійної Аiяльності: репродуктивного (визначає елементарні образотворчі Аії), продуктивного (забезпечує виробничі Аії), стабільно-продуктивного (відображає образотворчу манеру); творчого (забезпечує формування креативної манери образотворчих Аій) уможливило оцінювання результатів експериментального впровадження розробленої моделі образотворчої піАготовки.

ПіА час формувацьного експерименту в освітню практику запроваАжено модемь професійно зорієнтованої образотворчої підготовки як цімісний науково-методичний комплекс авторських принципів, методів, форм та прийомів педагогічної роботи. За підсумками операційного етапу було досягнуто віцьне орієнтування у художньо-культурологічному просторі майбутньої професії, збільшено та систематизовано образотворчий тезаурус, сформовано потребу та уявлення про методи саморозвитку засобами мистецтва, що зАійснено у хоАі опанування Аисциплін: «Історія мистецтв», «Кольорознавство», «Рисунок», «Живопис», пленерної практики. На праксеологічному етапі акцентовано соціокультурний та особистісний виміри формування образотворчої готовності у становменні індивідуахьної художньої манери, самостійному конструюванні вцасного шияху професійного зростання за результатами вивчення Аисциплін: «Рисунок» (III-IV), «Композиція», «Стицістика інтер'єру» (IV-VI), а також при виконанні робіт. Застосовані інновації забезпечими випереАжальний професійний розвиток, у їхній піАготовці не тільки як грамотних фахівців, але творців, зАатних застосовувати потенціац мистецтва при креативному розв'язанні актуальних завдань науки, освіти та практичної роботи.

Висновки. Таким чином, процес композиційного мислення скмаАається з чуттєвої і раціональної сторін, що виступають в тісній взаємодії. Працюючи наА художнім образом, хуАожник продумує ХУАожню Аію, Аһя народження художнього образу треба мати чуттєву базу АосвіАу. Композиційне мислення породжує Аумки, конструктивно-пластичне вираження поставценої задачі. Аля вирішення цих задач хуАожник зАійснює пошукову роботу, він віАтворює асоціативне моделювання, трансформуючи простір картини, римуючи угрупування форм з урахуванням статики і динаміки. Пошукове ескізування, що націкене на виявцення пластичного формоутворення, знаходження необхідних варіантів формо-думки, формо-образу, скмаАається в єАиний творчий процес, без якого неможАиво виразити почуття. Якщо почут тя безпосередньо впливають на піАбір уявлень, i їх зв'язок свідчить про стихійний асоціатив- 
ний процес, формо-знакове пластичне формоутворення вимагає віАповіАних навичок авторської Аіяльності, роботи в різних жанрах і навіть видах мистецтва. Принципи домінанти добре пояснюють емоційну скмадову і процесуальну специфіку, що зАійснює цілеспрямовану роботу.

Зважаючи на свою специфічність, композиційне мислення щільно пов'язане з іншими виАами та формами мислення, знаходиться в постійному взаємозв'язку з іншими формами мислення.

Перша помягає у використанні передових іАей загальнолюАського спрямування теоретичних положень та висновків інших наук, що орі$є$ нтують розробку нових концепцій візуального мистецтва, Аопомагають визначити вихіАні позиції цілеспрямування, мотиваційного спрямування творчих пошуків та розв'язання кон- кретних візуально-пластичних заАач Аля виявмення хуаожнього образу.

Аругою формою є запозичення методів АосліАження мислення. При цьому, чимало метоАів можуть бути аАаптовані в умовах універсалізації засобів пізнання та інтеграції знань, в галузі психомогії, філософії, математики, кібернетики та культурознавчого пошуку.

Третю форму становцять міждисципмінарні дослідження, в яких знання загацьних законів композиції, як гармонійного поєАнання частин і цілого, взаємодіють з різними видами образотворчого і візуацьного мистецтва, а з позиції культури розглядаються як унікальний творчий імпульс.

В сучасних умовах важмиве значення має необхідність розвитку феномену «композиційного мислення», забезпечує гармонійне поліфонічне звучання.

\section{Мітература}

1. Гергель Є. А. Психологічні особливості формування креативних зАібностей. Центр.

ін-т післядипАом. пеА. освіти АПН України. К.: 2007. 20 с.

2. Кобода О. В. Креативність як основа психічного зАоров’я особистості // Наука і освіта. Київ, 2010.

№ 3. C. 61-65.

3. Максименко О. Аизайнерська освіта - педагогічна культура // Мистецтво та освіта. Київ, 2005.

№ 3. С. 16.

4. Музиченко Ю. Розвиток творчих зАібностей майбутніх учителів - передумова формування мобільності // РіАна школа. Київ, 2006. № 9.32 с.

5. Пічкур М. Тренінг з композиції Аля майбутнього вчителя образотворчого мистецтва // Мистецтво та освіта. Київ, 1999. № 1.46 с.

6. Стась М. I. Методика формування творчих здібностей майбутніх учителів образотворчого мистецтва: [автореф. Аис... канА. пеА. наук]. Нац. пеА. ун-т ім. М. П. Арагоманова. К., 2007. 55 с. 7. Турчин В. В. Система розвиваючих дизайн-об॰єктів як елемент формування проектно-образного мислення // Традиції та новації у вищій архітектурно-художній освіті: Зб. ст. Харків, 1999. № 1. С. 32. 8. Турчин В. В. Базові аспекти процесу формування проектно-образного мислення // Вісник Харків. Аерж. академії дизайну і мистецтв. Харків, 2002. № 6. С. 265-267.

9. Свешников А. В. Композиционное мышление в изобразительном искусстве: автореф. Аис... Аоктора искусствоведения: 17.00.09. Рос. гос. пеА. ун-т им. А. И. Герцена. Санкт-Петербург, 2004. 52 с. 10. Музика О. Композиційні зАібності як основа художньо-творчої Аіяльності майбутніх учителів образотворчого мистецтва // Проблеми підготовки сучасного вчителя. 2010. № 2. С. 18-23.

11. Кайдановська О. О. Формування творчого мислення майбутніх учителів образотворчого мистецтва в процесі вивчення основ композиції: дис.... канА. пеА. наук: 13.00.02. К., 2004. 248 с.

12. Григор'єва В. Б. Формування навичок композиційної Аіяльності на початковому етапі навчання (в системі підготовки художників-педагогів): автореф. Аис. на зАобуття наук. ступеня канА. пеА. наук: спец. 13.00.02 «Теорія та методика навчання» (образотворче мистецтво). ОАеса, 1998. 20 с. 


\section{References}

1. Gergel` Ye. L. Psy`xologichni osobly`vosti formuvannya kreaty`vny`x zdibnostej. Centr. in-t pislyady` plom. ped. osvity`APN Ukrayiny`. K.: 2007. 20 s.

2. Loboda O. V. Kreaty`vnist` yak osnova psy`xichnogo zdorovıya osoby`stosti // Nauka i osvita. Ky`yiv, 2010. \# 3. S. 61-65.

3. Maksy`menko O. Dy`zajners `ka osvita - pedagogichna kul`tura // My`stecztvo ta osvita. Ky`yiv, 2005. \# 3. S. 16.

4. Muzy`chenko Yu. Rozvy`tok tvorchy`x zdibnostej majbutnix uchy`teliv - peredumova formuvannya mobil 'nosti // Ridna shkola. Ky`yiv, 2006. \# 9.32 s.

5. Pichkur M. Trening z kompozy`ciyi dlya majbutn`ogo vchy` telya obrazotvorchogo my`stecztva // My`stecztvo ta osvita. Ky`yiv, 1999. \# 1. 46 s.

6. Stas` M. I. Metody`ka formuvannya tvorchy`x zdibnostej majbutnix uchy`teliv obrazotvorchogo my`stecztva: [avtoref. dy`s... kand. ped. nauk]. Nacz. ped. un-t im. M. P. Dragomanova. K., 2007. 55 s.

7. Turchy`n V. V. Sy`stema rozvy`vayuchy`x dy`zajn-obıyektiv yak element formuvannya proektnoobraznogo my`slennya // Trady`ciyi ta novaciyi u vy`shhij arxitekturno-xudozhnij osviti: Zb. st. Xarkiv, 1999. \# 1. S. 32 .

8. Turchy`n V. V. Bazovi aspekty` procesu formuvannya proektno-obraznogo my`slennya // Visny`k Xarkiv. derzh. akademiyi dy`zajnu i my`stecztv. Xarkiv, 2002. \# 6. S. 265-267.

9. Sveshny`kov A. V. Kompozy`cy`onnoe mushleny`e v y`zobrazy`tel 'nom y`skusstve: avtoref. dy`s... doktora y`skusstvovedeny`ya: 17.00.09. Ros. gos. ped. un-t y`m. A. Y`. Gercena. Sankt-Peterburg, 2004. 52 s. 10. Muzy`ka O. Kompozy`cijni zdibnosti yak osnova xudozhn`o-tvorchoyi diyal `nosti majbutnix uchy`teliv obrazotvorchogo my`stecztva // Problemy` pidgotovky` suchasnogo vchy`telya. 2010. \# 2. S. 18-23.

11. Kajdanovs`ka O. O. Formuvannya tvorchogo my`slennya majbutnix uchy`teliv obrazotvorchogo my`stecztva v procesi vy`vchennya osnov kompozy`ciyi: dy`s.... kand. ped. nauk: 13.00.02. K., 2004. $248 \mathrm{s.}$ 12. Gry`gor yeva V. B. Formuvannya navy 'chok kompozy`cijnoyi diyal’nosti na pochatkovomu etapi navchannya (v sy`stemi pidgotovky` xudozhny 'kiv-pedagogiv): avtoref. dy`s. na zdobuttya nauk. stupenya kand. ped. nauk: specz. 13.00.02 «Teoriya ta metody`ka navchannya» (obrazotvorche my`stecztvo). Odesa, 1998. $20 \mathrm{~s}$.

\section{Николайчук Н. И. Композиционность в современной изобразительности: полифония ихи какофония?}

Аннотация. Статья рассматривает проблемы композиционности, гармоничности произведения в современном искусстве, Аоказывая, что органическое единство произведения возможно только при условии соблюдения композиционных законов. Важное значение автор придает анализу «визуального диалога» художественного произведения и зрителя, делая акцент на том, что благодаря такому подходу открывается возможность проникнуть в содержание произведения, почувствовать образ в целом. По мнению автора, композиционное восприятие служит необходимым инструментом, чтобы уметь видеть и чувствовать художественное произведение. В современном искусстве идут процессы «разгармонизации» произведения, и автор статьи доказывает, что при таких условиях искусство выступает в роли своеобразного «коммуникативного поля», гАе происходит Аиалог разАичных компонентов, формирующих общую культуру. Композиция выступает связующим компонентом, Аавая возможность панорамного взгляда на мир. Художественное произведение является своеобразным выразителем эстетики, интеллигентности, интелмектуального уровня художника, мерилом его моральных качеств. «Провокационность» современного искусства тоже межит в контексте этого Аискурса - отражая авторские рефлексии на вызовы и раздражители, она, тем не менее, имеет свои собственные «границы Аозволенного». На конкретных примерах автор статьи доказывает, что овладение законов композиционного мышления вызывает наличие этих границ, способность разАичать статику и динамику сюжета. Приводя паралмели в восприятии композиции и декомпозиции художником и искусствоведом, автор показывает общее и отличное в подходах к анаАизу одного и того же произведения. Процесс композиционного мышления состоит из чувственной и рациональной сторон, выступающих в тесном взаимодействии. Работая над художественным образом, художник продумывает художественную действие, в то время как критик Авижется обратным путем. Композиционное мышление порождает мысли, конструктивно-пластическое выражение по- 
ставценной задачи. Аля его решения художник осуществцяет поисковую работу, воспроизводит ассоциативное модемирование, трансформируя пространство картины, рифмуя группировки форм. Критик, пытаясь понять смыслы, заложенные в произведении, тоже помьзуется композиционным мышиением. Томько процесс раскрутки его творческой мысли обратный. От того, насколько совершенно одни и Аругие обладают навыками композиционного мышкения и восприятия, зависит результат успешности их профессионацьной деятемьности.

При таких условиях открывается современная полифоничность звучания, при Аругих звук приобретает какофонические характеристики. Что из этого выбирать - решать художнику.

Ключевые слова: изобразитемьное искусство, композиционное мышление, современное искусство.

\section{Nicolaychuk N. I. Compositionality in contemporary art: polyphony or cacophony?}

Abstract. The article deals with the problems of compositionality, harmony of the work in contemporary art, proving that the organic unity of a work is possible only subject to the observance of compositional laws. The author attaches importance to the analysis of the «visual dialogue» of the artistic work and the viewer, emphasizing the fact that this approach opens the opportunity to penetrate into the content of the work, to feel the image in general. According to the author, compositional perception serves as the necessary tool to be able to see and feel the work of art. In contemporary art, the processes of «harmonizing» the work are taking place, and the author of the article argues that under such conditions, art acts as a peculiar «communicative field», where the dialogue of various components forming a common culture takes place. The composition acts as a connecting component, giving a panoramic view of the world. The artistic work is a peculiar expression of aesthetics, intelligence, intellectual level of the artist, a measure of his moral qualities. The "provocative» nature of contemporary art, too, lies in the context of this discourse, reflecting author s reflections on challenges and stimuli; nevertheless, it has its own «limits allowed». In concrete examples, the author of the article argues that the mastery of the laws of compositional thinking leads to the presence of these boundaries, the ability to distinguish between the statics and the dynamics of the plot. Bringing parallels in the perception of composition and decomposition by the artist and art historian, the author shows a common and different approach to the analysis of one and the same work. The process of composing thinking consists of sensory and rational sides that act in close interaction. Working in an artistic way, the artist thinks artistic action, while the critic moves in the opposite direction. Compositional thinking generates thoughts, constructive-plastic expression of the task. For his decision, the artist carries out search work, reproduces associative modeling, transforming the space of the painting, rhyme grouping forms, Critic, trying to grasp the meanings laid down in the work, also uses compositional thinking. Only the process of promoting his creative thinking is reversible. From how perfectly one and the other possess the skills of compositional thinking and perception - the result of the success of their professional activity depends.

Under these conditions, the modern polyphonic sound is opened, for the rest - the sound gets cacophonic characteristics. What to choose from is to decide the artist.

Key words: fine art, compositional thinking, contemporary art. 